\title{
In Vitro Corrosion of Quaternery Magnesium Alloy Foam by Addition of Zinc
}

\author{
Franciska Pramuji Lestari ${ }^{1 \mathrm{a}}$, Sofia Marta ${ }^{2 \mathrm{~b}}$, Aprilia Erryan ${ }^{1 \mathrm{c}}$, Inti Mulyati ${ }^{1 \mathrm{~d}}$, Ika Kartika ${ }^{\text {le }}$ \\ la,c,d,e,f Research Center for Metallurgy and Materials, Indonesian Institute of Sciences (LIPI) \\ Kawasan PUSPIPTEK Gd. 470 Tangerang Selatan, Banten, 15314 \\ 2b Metallurgical Engineering-Universitas Sultan Agung Tirtayasa \\ Jalan Raya Jakarta Km 4, Serang, Banten, 42124
}

\begin{tabular}{l}
\hline \multicolumn{1}{c}{ Article Info } \\
\hline Article History: \\
Received Oct 1, 2020 \\
Revised Oct 14,2020 \\
Accepted Oct 21,2020 \\
\hline
\end{tabular}

Keywords:

Calibration

Positive Pressure

Vacuum Pressure

Leakage Test

\begin{abstract}
Magnesium alloys have been intensively studied as possible resorbable material with adequate mechanical properties similar to natural bones but very poor corrosion properties. In this analysis, the addition of $\mathrm{Zn}$ element to quaternary $\mathrm{Mg}-\mathrm{Ca}-\mathrm{Zn}$ alloy foam was evaluated with $\mathrm{TiH} 2$ as a foaming agent and manufactured with high-purity raw materials the powder metallurgy process. In Hank's solution, the rate of corrosion of specimens by direct observations with Scanning Electron Microscopy (SEM), Electron Dispersion Spectrometry (EDS), static immersion studies, potentiodynamic evaluations, and X-Ray Diffraction (XRD). The specimen's post-immersion characteristics and the corresponding Hank's solutions were examined at 2, 4, 6, 24, 48, and 72 hours of immersion. The findings show that the microstructure of alloy morphology, such as pores, pitting corrosion, needle shapes, and galvanic corrosion has the main corrosion products $\mathrm{Mg}(\mathrm{OH}) 2$ and $\mathrm{Ca} 10(\mathrm{PO} 4) 6(\mathrm{OH}) 2$. The addition of less than 6 percent $\mathrm{wt} \mathrm{Zn}$ will minimize the corrosion rate but increase with 10 percent wt $\mathrm{Zn}$. From this study, Mg-Zn-Ca alloy at 6 percent wt $\mathrm{Zn}$ has the lowest corrosion rate with slow pH changes in the process.
\end{abstract}

\author{
Corresponding Author: \\ fran011@lipi.go.id, \\ Research Center for Metallurgy and Materials \\ Indonesian Institute of Sciences
}

This work is an open-access article and licensed under a Creative Commons Attribution-ShareAlike 4.0 International License (CC BY-SA 4.0).

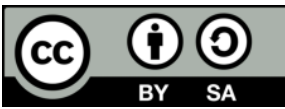

\section{INTRODUCTION}

$\mathrm{Mg}$ alloys have strong biodegradability, but their rapid degradation is the most formidable obstacle to their successful use. Low corrosion and high strength are the main requirements

for the selection of biodegradable and biocompatible metals. [1]. Their laxity due to stress-shielded bone resorption, weak interfacial bonding between the implant and the bone, and lack of biological anchorage for forming tissue have been the biggest problem with solid-structure metal implants [2]. Much effort has been made to create and classify metal implants with microstructures and properties similar to trabecular bones to resolve these issues, such as metal foams, metallic scaffolds, porous metals, or cellular metals. In this research, we used $\mathrm{TiH}_{2}$ as a foaming agent to form pores in $\mathrm{Mg}$ alloy. $\mathrm{TiH} 2$ is regarded as the strongest foaming hydride and is also used to foaming low melting point metals such as magnesium. A significant amount of hydrogen in $\mathrm{TiH} 2$ is produced during heating, resulting in pores in $\mathrm{Mg}$ alloy [3]. Porous metal is expected to provide better interaction with bones and good osteointegration with bone host tissue. This is mostly attributed to a high rate of growth of bone on porous surfaces and transport through the pores of body fluids, resulting in stronger interlocking or fixation between implants and bone. In regards to corrosion and biodegradability, once the bone has healed without reoperation, the presence of pores contributes to smooth implant deterioration. However, the mechanical stability of the pore $\mathrm{Mg}$ alloy at the time of implantation is limited. A very critical stabilizing biodegradable magnesium clip should be positioned around the biological graft before the latter achieves adequate equilibrium to prevent premature dissolution or aneurysm formation [4].

The weak corrosion resistance of $\mathrm{Mg}$ alloys is the most troublesome of alloys [5][6][7]. It should think back that corrosion on the surface affects $\mathrm{Mg}$ alloys, particularly for orthopedic implants [8]. However, the rapid rate of degradation of magnesium alloy is a biomedical material. This 
results in high levels of ion and hydrogen gas release and subcutaneous emphysema [9]. Not only can the alloy portion improve the mechanical properties of the magnesium alloy, but it can also increase the corrosion resistance. Added Mn has been reported to reduce the adverse effects of Fe impurity on the corrosion properties of magnesium alloys. [10]. Aluminum-containing magnesium alloy can form a thick passivation film that protects the alloy from corrosion rapidly, but aluminum can cause Alzheimer's in the long term [11][12]. A combination of improved strength and ductility comes from alloying $\mathrm{Mg}$ with $\mathrm{Zn}$ [5]. In addition, $\mathrm{Zn}$ is a microelement and part of a variety of proteins that our body requires. $\mathrm{Zn}$ can also improve cell metabolism. In the previous study, the elements $\mathrm{Zn}$ and $\mathrm{Mn}$ were chosen to create a biomedical magnesium alloy. The findings have shown that $\mathrm{Zn}$ can significantly increase the mechanical properties of as-cast $\mathrm{Mg}$ Mn alloy and its corrosion resistance [13]. The primary research findings in this study focused on the impact of $\mathrm{Zn}$ on the corrosion resistance of $\mathrm{Mg}-\mathrm{Ca}-\mathrm{Zn}$ metal foam and the use of $\mathrm{TiH} 2$ as a foaming agent, and the prospect of the use of $\mathrm{Mg}$ alloy as a bone implant. The mechanical properties of $\mathrm{Zn}$ porous magnesium and the inclusion of $\mathrm{TiH} 2$ as an extensively researched foaming agent revealed that this substance retained a low compressive strength with improved porosity in order to prevent stress shielding [14].

\section{MATERIALS AND METHODS}

High purity magnesium (Merck KGaA, 98.5 percent pure, D 0.06-0.3 mm), zinc (Merck KGaA, D $<45 \mu \mathrm{m}$ ), and $\mathrm{Ca}$ granule (Merck KGaA, $>98.5$ percent pure, $\mathrm{D}<2.6 \mathrm{~mm}$ ) as starting materials and $\mathrm{TiH} 2$ fine powder as a foaming agent (98 percent pure) were used for the preparation of foaming precursors. $\mathrm{Mg}-\mathrm{Zn}-\mathrm{Ca}$ alloys have been prepared using a powder metallurgy process. $\mathrm{TiH} 2$ was heat-treated at $450^{\circ} \mathrm{C}$ for $120 \mathrm{~min}$ in argon to move the hydrogen release range to higher temperatures necessary for a reasonable foam structure. [3]. In this study, the design compositions were $\mathrm{Mg}-\mathrm{Zn}-\mathrm{Ca}$ with 3, 6, and 10\% $\mathrm{Zn}(\% \mathrm{wt})$ and 3, 5, and $10 \% \mathrm{TiH}_{2}(\% \mathrm{wt})$. Subsequently, the milled powders were compacted using a hydraulic press at room temperature in a cylindrical die with a $10 \mathrm{~mm}$ diameter under 200 psi pressure for $5 \mathrm{~min}$. In argon condition, the green compact was sintered at $600^{\circ} \mathrm{C}$ with a holding time of 5 hours and then cooled naturally to reach ambient temperature, and the heating rate was $5^{\circ} \mathrm{C} /$ minute. The degradation behavior of these $\mathrm{Mg}$-based materials is then explored through the implementation of electrochemical and immersion research techniques, the surface characteristics of SEM and EDS, and XRD has described the phases developed during the corrosion process.

\section{1) Electrochemical Test}

Electrochemical techniques, such as potentiodynamic polarization (PDP) experiments, provide a fast comparison of different $\mathrm{Mg}$ alloys degradation profile. As the first test of degradation characterization, this method is commonly used [15]. In this research, in vitro corrosion was performed in electrochemical studies using the G750 potentiostat Gamry instrument. For electrochemical measurements, a three- electrode cell was used. The carbon electrode and the calomel electrode (SCE) were used as a counter electrode and as a reference electrode. $\mathrm{Mg}$ alloy foam was used as a working electrode with an exposure area of $1 \mathrm{~cm} 2$. The simulated body liquid electrolyte Hank's solution was used as a medium at 37 $\circ \mathrm{C}$ and a $\mathrm{pH}$ value of 7.4. The electrolyte volume used for each experiment was $200 \mathrm{ml}$. The theoretical range of scanning was $-200 \mathrm{mV}$ to $+200 \mathrm{mV}$ with a scanning rate of 0.5 $\mathrm{mV} / \mathrm{s}$. The temperature of the electrolyte was held at $37 \pm 2^{\circ}$ C. The rate of corrosion was calculated using the Tafel extrapolation process.

\section{2) Immersion Test}

The immersion test was carried out in compliance with ASTM $\mathrm{G}$ 31-72. Hank's solution was used and performed at $37^{\circ}$ Cand $7.4 \mathrm{pH}$ for 72 hours in a water bath [16]. Table 1 shows the composition of Hank's solution. After air drying, the specimens were weighed. The immersion test was conducted by observing the normal amount of human blood plasma excretion in which approximately $14 \mathrm{~mL}$ of body fluids out of $30 \mathrm{~mL}$ were replaced with fresh fluids each day [17].

TABLE 1. COMPOSITION OF HANK'S SOLUTION [18]

\begin{tabular}{cc}
\hline Component & Concentration $(\mathrm{g} / \mathrm{L})$ \\
\hline $\mathrm{NaCl}$ & 8.0 \\
$\mathrm{KCl}$ & 4.0 \\
$\mathrm{CaCl}_{2}$ & 0.14 \\
$\mathrm{MgSO}_{4} .7 \mathrm{H}_{2} \mathrm{O}$ & 0.1 \\
$\mathrm{NaHPO}_{4}$ & 0.048 \\
$\mathrm{NaHCO}_{3}$ & 0.35 \\
$\mathrm{Glucose}$ & 0.35 \\
$\mathrm{KH}_{2} \mathrm{PO}_{4}$ & 0.6 \\
$\mathrm{MgCl}_{2} .6 \mathrm{H}_{2} \mathrm{O}$ & 0.1 \\
\hline \hline
\end{tabular}

\section{3) $S E M, E D S$, and $X R D$}

To describe the morphology and composition of the sample, the scanning electron microscope (SEM), JEOL, JSM-6390A, fitted with an energy dispersive X-ray ( EDX) analyzer, was used. The phase composition of the $\mathrm{Mg}$ alloys after immersion was investigated by X-ray diffractometry (XRD: D / MAX255) with $\mathrm{Cu}-\mathrm{K} \alpha 1$ radiation (wavelength $\lambda=1.5406 \AA$ ). The voltage of the tube and the XRD electric tube current were 40 $\mathrm{kW}$ and $250 \mathrm{~mA}$, respectively.

\section{III.RESULTS}

\section{4) Electrochemical Test Result}

The potentiodynamic polarization tests identify the alloy's corrosion behavior and based on short testing time, estimate their corrosion rates. Fig. 1 shows the Tafel curves of the foam of all $\mathrm{Mg}$ alloys. Table 2. lists the corrosion potential (Ecorr), current density, and corrosion rates (Icorr). The lowest corrosion potential and low current density were shown by the $\mathrm{Mg}-1 \mathrm{Ca}$ alloy of $6 \mathrm{wt} . \% \mathrm{Zn}$ and $10 \mathrm{wt} \% \mathrm{TiH}_{2}$. 
The addition of $\mathrm{Zn}$ to $6 \mathrm{wt} . \%$ substantially changed the corrosion capacity to a nobler. Low corrosion rates were obtained when 10 wt. $\% \mathrm{Zn}$ and 3 wt. $\% \mathrm{TiH}_{2}$ were added in $\mathrm{Mg}-1 \mathrm{Ca}$ alloy.
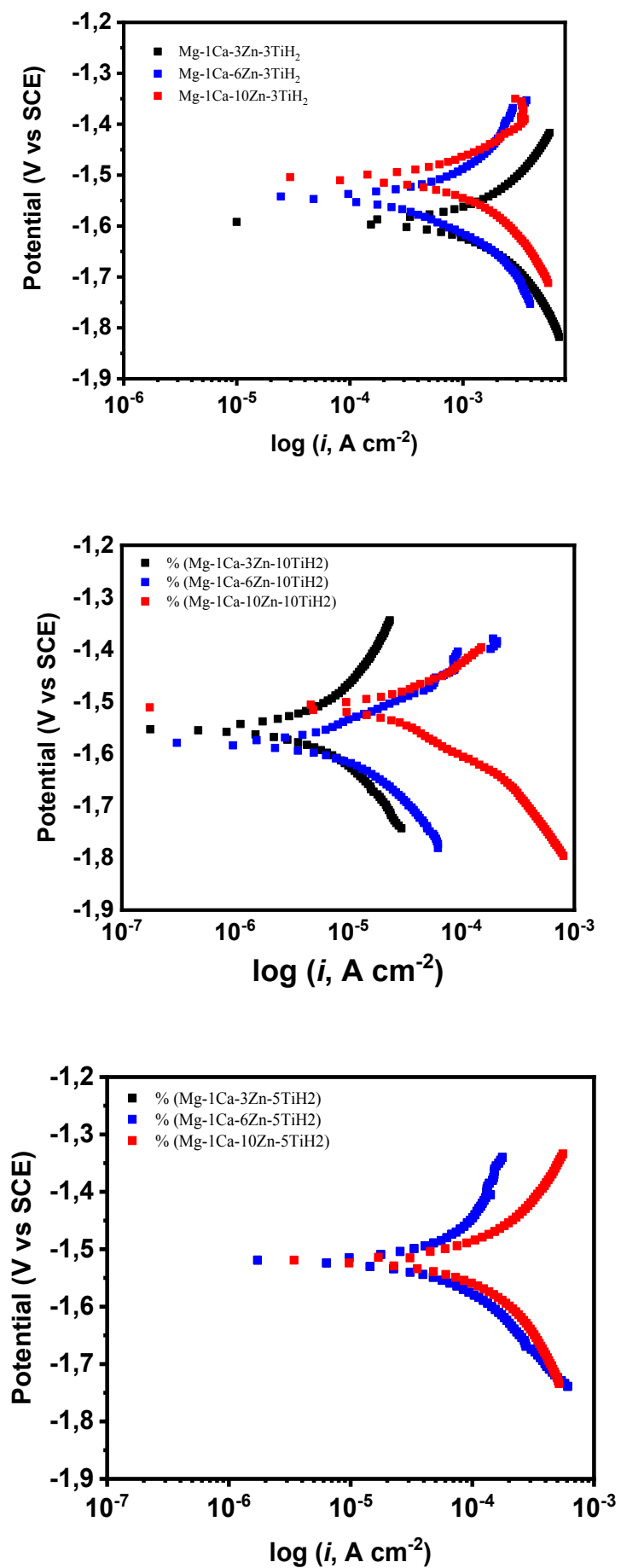

Fig. 1. Potentiodynamic polarization curve magnesium alloy with the variation of A. 3 wt. $\%$; B. 5 wt.\% and C. 10 wt.\% of $\mathrm{TiH}_{2}$
TABLE 2. CORROSION RATE DURING THE POTENTIODYNAMIC TEST

\begin{tabular}{llc}
\hline \hline \multirow{2}{*}{ Composition } & \multicolumn{2}{c}{ Potentiodynamic Polarization } \\
\cline { 2 - 3 } & I Corr (A) & $\begin{array}{c}\text { Corrosion Rate } \\
\text { (mmpy) }\end{array}$ \\
\hline Mg-Ca-3Zn-3TiH 2 & 0.00078 & 19.286 \\
Mg-Ca-6Zn-3TiH 2 & 0.00067 & 26.615 \\
Mg-Ca-10Zn-3TiH 2 & 0.00031 & 43.066 \\
Mg-Ca-3Zn-5TiH 2 & 0.00108 & 1.499 \\
Mg-Ca-6zn-5TiH 2 & 0.000189 & 4.071 \\
Mg-Ca-10Zn-5TiH 2 & 0.0591 & 7.525 \\
Mg-Ca-3Zn-10TiH & 0.000491 & 0.731 \\
Mg-Ca-6Zn-10TiH 2 & 0.00000057 & 0.385 \\
Mg-Ca-10Zn-10TiH & 0.0000184 & 1.499 \\
\hline \hline
\end{tabular}

\section{5) Immersion Test Result}

In the static immersion test, the impact of exposure time was well established. The variation of $\mathrm{pH}$ during 72 hours of the process of corrosion as the function of immersion time is shown in Fig.2. The Mg alloys's $\mathrm{pH}$ changed slowly in the whole process, and the highest $\mathrm{pH}$ occurred at 24 hours immersion with 10 wt.\% $\mathrm{Zn}$ addition. The $\mathrm{pH}$ of $\mathrm{Mg}$ alloy with 6 wt.\% $\mathrm{Zn}$ changed relatively slowly and reached the highest $\mathrm{pH}$ at 72 hours.

TABLE 3. THE CHANGE OF CORROSION RATE AND PH DURING IMMERSION TEST

\begin{tabular}{|c|c|c|c|c|c|c|c|}
\hline \multirow{3}{*}{ Composition } & \multicolumn{7}{|c|}{ Static Immersion Test } \\
\hline & $\begin{array}{l}\text { Corr } \\
\text { Rate }\end{array}$ & $\mathrm{pH}$ & $\mathrm{pH}$ & $\mathrm{pH}$ & $\mathrm{pH}$ & $\mathrm{pH}$ & $\mathrm{pH}$ \\
\hline & (mmpy) & $\begin{array}{c}2 \\
\mathrm{hrs}\end{array}$ & $4 \mathrm{hrs}$ & $6 \mathrm{hrs}$ & $\begin{array}{l}24 \\
\text { hrs }\end{array}$ & $\begin{array}{l}48 \\
\text { hrs }\end{array}$ & $\begin{array}{l}72 \\
\text { hrs }\end{array}$ \\
\hline $\begin{array}{c}\text { Mg-Ca-3Zn- } \\
\mathrm{TiH}_{2}\end{array}$ & 27.54 & 9.07 & 10.03 & 10.37 & 11.50 & 11.57 & 11.00 \\
\hline $\begin{array}{c}\mathrm{Mg}-\mathrm{Ca}-6 \mathrm{Zn}- \\
3 \mathrm{TiH}_{2}\end{array}$ & 14.80 & 8.10 & 9.45 & 9.70 & 11.25 & 10.85 & 11.30 \\
\hline $\begin{array}{c}\text { Mg-Ca- } \\
10 \mathrm{Zn}-3 \mathrm{TiH}_{2}\end{array}$ & 34.63 & 8.17 & 11.17 & 11.50 & 11.70 & 11.37 & 11.03 \\
\hline $\begin{array}{l}\mathrm{Mg}-\mathrm{Ca}-3 \mathrm{Zn}- \\
5 \mathrm{TiH}_{2}\end{array}$ & 28.43 & 9.75 & 10.95 & 11.45 & 11.85 & 11.85 & 11.50 \\
\hline $\begin{array}{c}\text { Mg-Ca-6Zn- } \\
5 \mathrm{TiH}_{2}\end{array}$ & 28.08 & 9.33 & 10.43 & 11.03 & 11.93 & 11.67 & 11.53 \\
\hline $\begin{array}{c}\mathrm{Mg}-\mathrm{Ca}- \\
10 \mathrm{Zn}-5 \mathrm{TiH}_{2}\end{array}$ & 34.70 & 9.90 & 11.10 & 11.70 & 11.95 & 12.00 & 11.55 \\
\hline $\begin{array}{l}\mathrm{Mg}-\mathrm{Ca}-3 \mathrm{Zn}- \\
10 \mathrm{TiH}_{2}\end{array}$ & 30.51 & 9.20 & 10.30 & 10.60 & 11.90 & 11.70 & 11.20 \\
\hline $\begin{array}{c}\mathrm{Mg}-\mathrm{Ca}-6 \mathrm{Zn}- \\
10 \mathrm{TiH}_{2}\end{array}$ & 24.09 & 8.60 & 10.50 & 11.05 & 11.70 & 11.60 & 11.60 \\
\hline $\begin{array}{l}\mathrm{Mg}-\mathrm{Ca}- \\
10 \mathrm{Zn}-10 \mathrm{TiH}_{2}\end{array}$ & 39.47 & 8.40 & 10.90 & 11.05 & 11.30 & 11.25 & 11.23 \\
\hline
\end{tabular}


Journal of Electronics, Electromedical, and Medical Informatics (JEEEMI)

Vol. 2, No. 3, October 2020, pp. 86-92

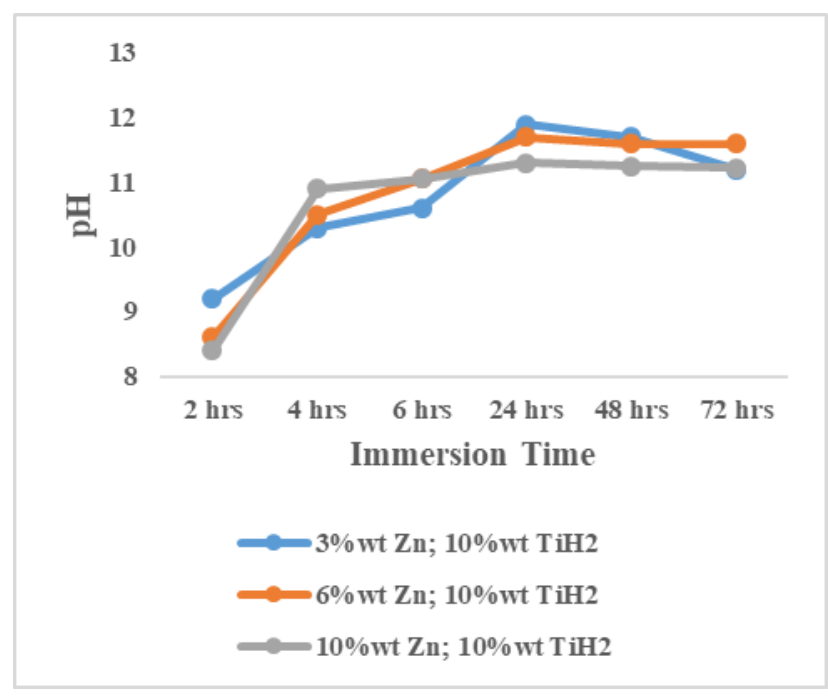

Fig. 2. Change of $\mathrm{pH}$ value during the immersion test

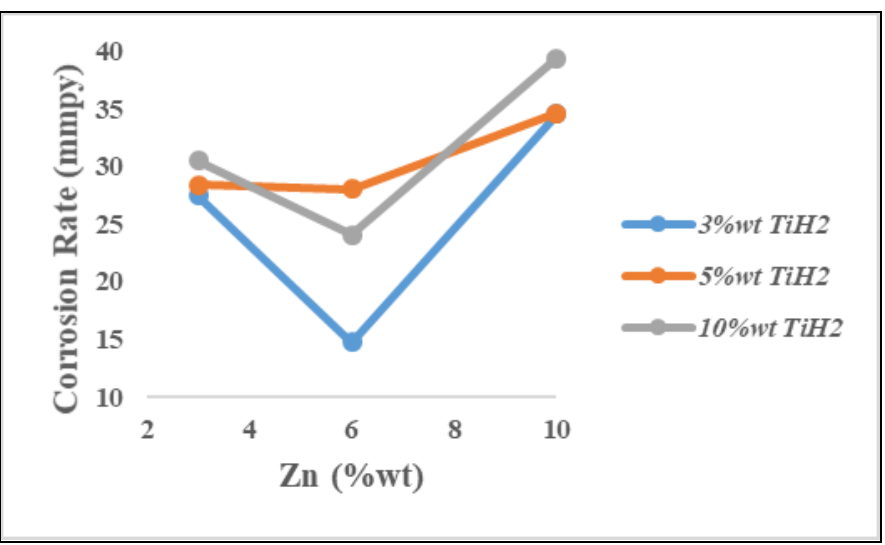

Fig 3. The corrosion rate of $\mathrm{Mg}$ alloys in immersion test

6) Scanning Electron Microscopy (SEM )and Energy Dispersive Spectroscopy (EDS) Result

The surface morphologies of specimens of $\mathrm{Mg}$ alloys after static immersion test in Hank's solution after 72 hours are shown in Fig. 4a, b and c. Some corrosion product formed on the surface of the $\mathrm{Mg}$ alloy, especially on the corroded region, and as immersion time increased, some detached from the surface. Consequently, the surface of $\mathrm{Mg}$ is filled with several pits of varying depths and sizes.

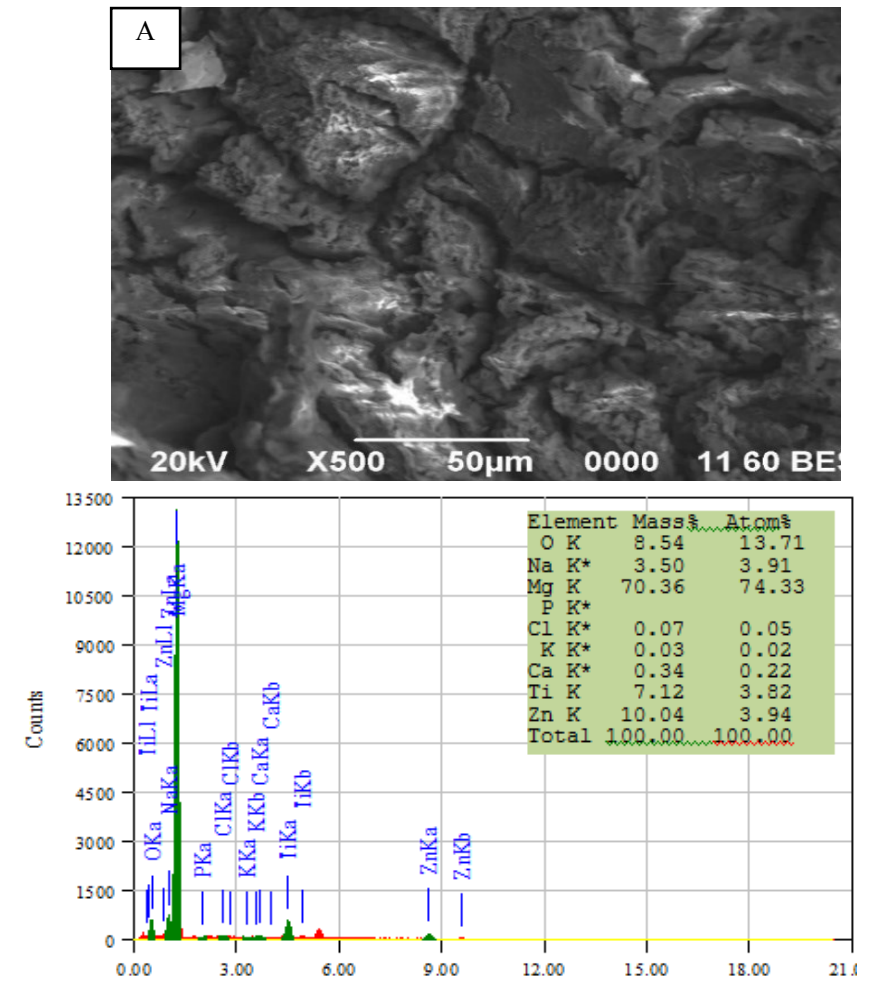

$\mathrm{keV}$
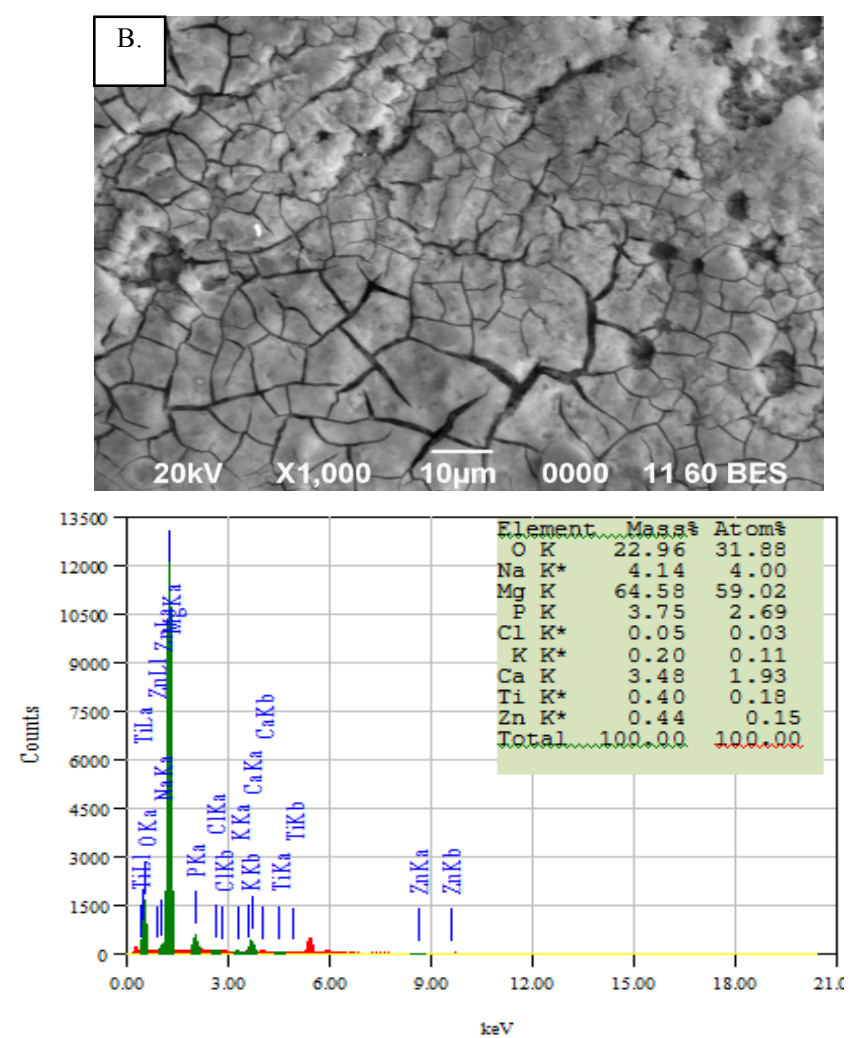


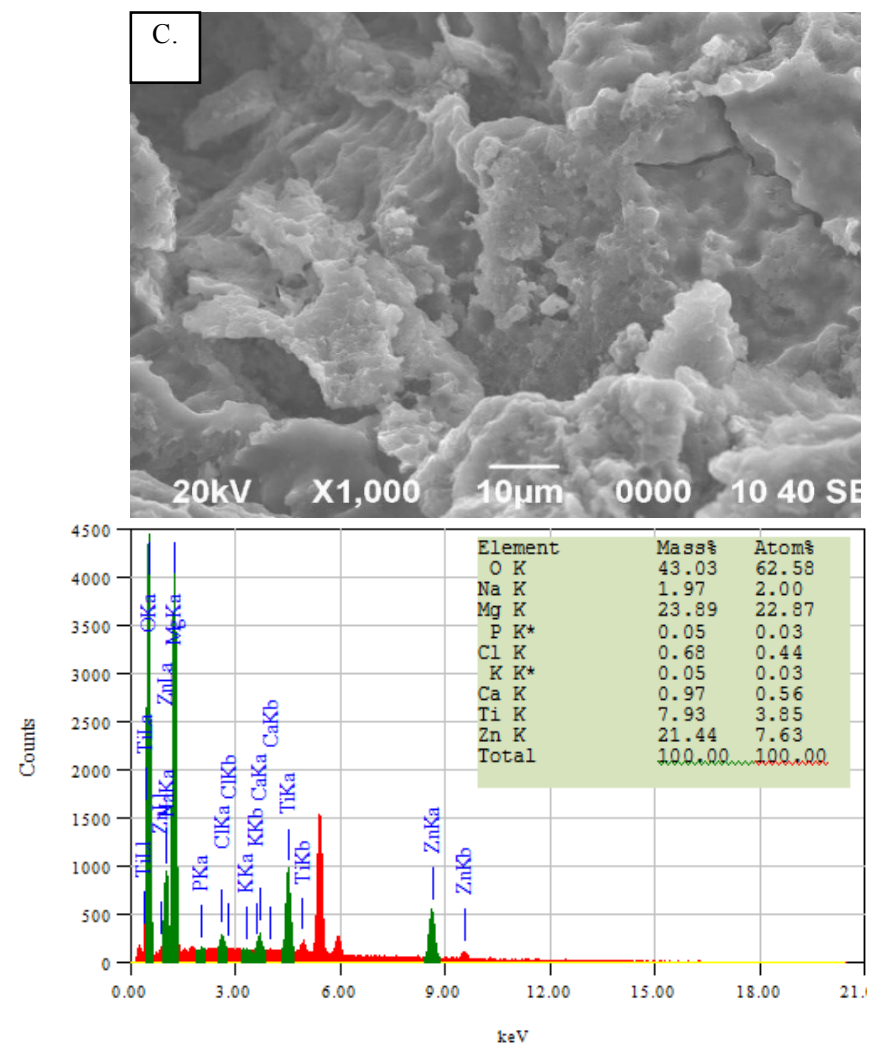

Fig. 4. SEM and EDS of Mg alloy after immersion test (a) $\mathrm{Mg}-1 \mathrm{Ca}-3 \mathrm{Zn}$ $10 \mathrm{TiH}_{2}$, (b) Mg-1Ca-6Zn-10 TiH 2 , and (c) Mg-1Ca-10Zn-10TiH

\section{7) XRD (X-Ray Diffraction) Result}

Products of corrosion on $\mathrm{Mg}$ alloys foam after the immersion test were identified using XRD analysis. $\mathrm{MgZn}$, $\mathrm{TiH}, \mathrm{MgO}, \mathrm{Ca}_{10}\left(\mathrm{PO}_{4}\right)_{6}(\mathrm{OH})_{2}$ and $\mathrm{Mg}(\mathrm{OH})_{2}$ peaks were found after the immersion test for 72 hours as shown in Fig. 5.

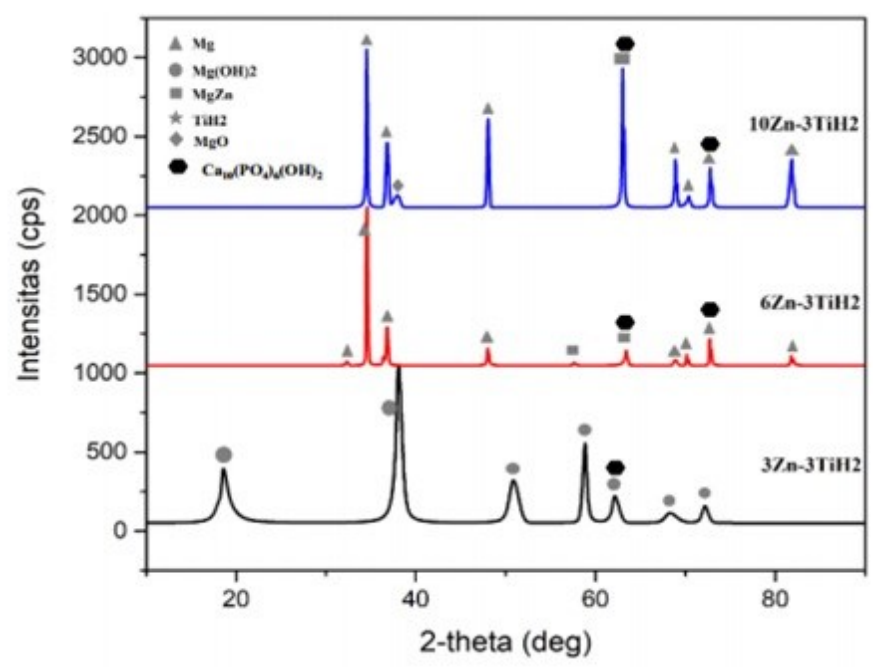

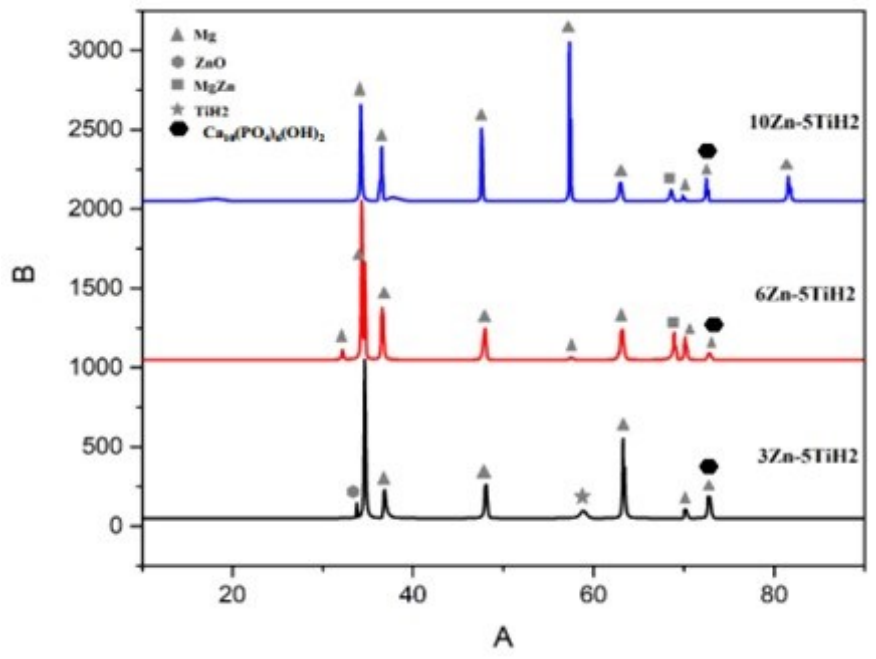

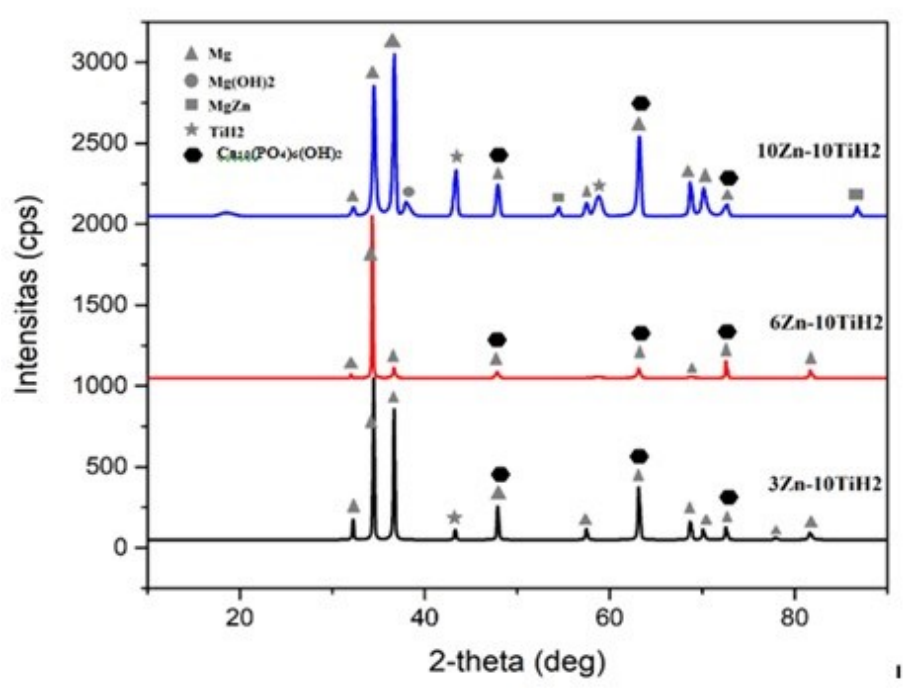

Fig. 5. XRD analysis after immersion test with different $\mathrm{TiH}_{2}$ contents

\section{DISCUSSION}

Corrosion, as a product of a surface impact and the substrate, entails material deterioration. It affects the parameters and the degree of corrosion greatly. The following reactions may include the overall degradation phase of magnesium and its alloys:

(anodic reaction)

$\mathrm{Mg}(\mathrm{s}) \rightleftharpoons \mathrm{Mg}^{2+}(\mathrm{aq})+2^{\mathrm{e}-}$

(cathodic reaction)

$2 \mathrm{H}_{2} \mathrm{O} \quad(\mathrm{aq}) \rightleftharpoons 2^{\mathrm{e}-}+\mathrm{H}_{2}(\mathrm{~g})+2 \mathrm{OH}^{-}(\mathrm{aq})$

(product formation)

$\mathrm{Mg}^{2+}(\mathrm{aq})+2 \mathrm{OH}^{-}(\mathrm{aq}) \rightleftharpoons \mathrm{Mg}(\mathrm{OH})_{2}(\mathrm{~s})$ 
Magnesium hydroxide or $\mathrm{Mg}(\mathrm{OH})_{2}$ is concentrated on the underlying $\mathrm{Mg}$ as an anticorrosion agent which becomes a protective layer against water corrosion. The chloride $\mathrm{Cl}$ concentration of chloride $(\mathrm{Cl})$ increase above $30 \mathrm{mmol} /$ liter in the corrosive environment, it begins to turn into highly soluble $\mathrm{MgCl}_{2}$ [19]. In Hank's solution, $\mathrm{Cl}$ ions $\left(\mathrm{Cl}^{-}\right)$can move through the layer and react easily together $\mathrm{Mg}(\mathrm{OH})_{2}$ to initiate the $\mathrm{MgCl}_{2}$ that more soluble and then dissociate become $\mathrm{Mg}^{2+}$ and $2 \mathrm{Cl}^{-}$ions, allowing $\mathrm{OH}^{-}$near the $\mathrm{Mg}$ alloys surface. The layer of $\mathrm{Mg}(\mathrm{OH})_{2}$ is detached and allows its more active at the surface. The area that protected has also begun to decrease. In addition, increasing the solution's $\mathrm{pH}$, stabilized $\mathrm{Mg}(\mathrm{OH})_{2}$, which was obtained with the $\mathrm{OH}^{-}$released from the reaction of cathode [20]. The rise in interfacial $\mathrm{pH}$ was caused by targeting the $\mathrm{Cl}^{-}$on $\mathrm{Mg}(\mathrm{OH})_{2}$ [21]. However, the alkalization levels of the solutions declined with the deposition of $\mathrm{Mg}(\mathrm{OH})_{2}$ and precipitation of other compounds on immersion samples[20]. It may be seen that the solution's alkalization rates are directly linear to the immersed samples corrosion rates and lower rates of $\mathrm{pH}$ factor rise exist as a result of lower corrosion rates. According to Fig. 1, samples with 6 wt.\%, Zn had a lower curve slope of $\mathrm{pH}$ in relation to the other alloys, because of their lower corrosion rates.

As shown in Fig. 3, based on the immersion test, the addition of $3 \%$ and $6 \mathrm{wt}$. Zn percent lowered the corrosion risk of the $\mathrm{Mg}$ alloy. The formation of active cathodic protection produces two ion concentration surfaces that transfer away from the aqueous solution layer to the magnesium surface (anodic site). Galvanic corrosion on the magnesium surfaces can be facilitated by the reaction between the various metals. Owing to the inhomogeneous composition of the surface and by the lectrolyte medium, it promotes the motion of ions. The galvanic corrosion in $\mathrm{Mg}$ with $\mathrm{Zn}$ alloy is due to the formation of $(\alpha-\mathrm{Mg}+\mathrm{Zn})$ phase, containing $\left(\alpha-\mathrm{Mg}+\mathrm{Ca}_{2} \mathrm{Mg}_{6} \mathrm{Zn}_{3}\right)$ on its surface [22]. The $\mathrm{Mg}-\mathrm{Zn}-\mathrm{Ca}$ corrosion rate can also decrease because $\mathrm{Zn}$ has a higher electronegativity. When $\mathrm{Zn}$ was added at more than $7 \mathrm{wt} \%$, it will accelerate the corrosion rate because the maximum limit solubility of $\mathrm{Zn}$ in $\mathrm{Mg}$ alloy is $7 \%$. If $\mathrm{Zn}$ is added more than $7 \%$, it will reduce corrosion resistance [23]. The electrochemical behavior of the $\alpha-\mathrm{Mg}$ matrix has a lower potential than intermetallic $\mathrm{MgZn}$ potential so that it acts as a cathode and causes corrosion of galvanic. Therefore, the rate of corrosion in $\mathrm{Mg}$ alloy is decreased.

$\mathrm{Mg}$ acts as an anode and the cathode reaction, such as grain boundary and secondary phases, occurs in the most peculiar location of the substrates. $\mathrm{Mg}$ particles were released into the electrolyte at the start of the electrochemical test to strike the region around the grain boundary. Processes of degradation prefer to focus on grain boundaries so they can finally be weakened. Mechanisms of corrosion tend to depend on grain limits until they can eventually be damaged. For defects such as grain boundary, $\mathrm{Mg}$ is more vulnerable to corrosion attacks. The secondary phase presence plays the same function as raising the area of the grain boundary. If the secondary process is concentrated on several sides only, the galvanic local corrosion attack can increase [22]. Based on SEM-EDS analysis, the alloy tends to experience damage in the form of pitting corrosion that forms small holes on the alloy and there are needle shapes. Fig. 4 describes the results of the microstructure analysis of $\mathrm{Mg}-\mathrm{Zn}-\mathrm{Ca}$ alloy using SEM-EDS. The phenomenon is similar to other studies. The picture shows that the metal surface is damaged, including cracks in the grain boundary and many holes generated around them. It indicates pitting corrosion. According to the findings of the EDS study, the corrosion products produced on the samples were essentially in the $\mathrm{O}, \mathrm{P}, \mathrm{Mg}, \mathrm{Ca}, \mathrm{Zn}$, and $\mathrm{Ti}$. The holes formed in the shapes of small holes and needles are indicated to contain $\mathrm{Mg}, \mathrm{Cl}$, and $\mathrm{O}$, which are interpreted as $\mathrm{MgCl}_{2}$ and $\mathrm{Mg}(\mathrm{OH})_{2}$ [1]. As can be seen in Fig. 4b, the EDS data of $\mathrm{Mg}$ alloy with $6 \mathrm{wt} . \% \mathrm{Zn}$ and $10 \mathrm{wt} . \% \mathrm{TiH}_{2}$. This figure revealed lowest corrosion product of $\mathrm{Cl}$, probably due to zinc ions $\left(\mathrm{Zn}^{+2}\right)$ reacting with hydrochloric acid $(\mathrm{HCl})$ and forming $\mathrm{Zn}$ $\mathrm{Cl}$. Due to the attack of $\mathrm{Cl}^{-}$, the damage of $(\mathrm{MgOH})$ film is reduced.

A white powder was found after 72 hours and it coated the surface of all the samples. Corrosion of magnesium alloys is primarily caused by the response of $\mathrm{Mg}+2 \mathrm{H}_{2} \mathrm{O} \rightarrow$ $\mathrm{Mg}(\mathrm{OH})_{2}+\mathrm{H}_{2}$. As the primary corrosion element, the solid substance of $\mathrm{Mg}(\mathrm{OH})_{2}$ is thus produced. Subsequently, the $\mathrm{pH}$ value of Hank's solution also increases when the rise in immersion time induces the deposition of $\mathrm{Mg}(\mathrm{OH})_{2}$ and the accumulation of calcium phosphate on the surface of the alloy [24]. On the other hand, Fig.5 shown, the increase of $\mathrm{Zn}$ in alloy at $10 \mathrm{wt} . \%$ produces the highest peak of $\mathrm{Ca}_{2} \mathrm{Mg}_{6} \mathrm{Zn}_{3}$ and $\alpha-\mathrm{Mg}$. This phenomenon can increase the risk corrosion of galvanic because of potential differences between $\alpha-\mathrm{Mg}$ and the $\left(\mathrm{Ca}_{2} \mathrm{Mg}_{6} \mathrm{Zn}_{3}+\alpha-\mathrm{Mg}\right)$ as secondary phase [25].

\section{CONCLUSION}

The $\mathrm{Mg}-\mathrm{Ca}-\mathrm{Zn}-\mathrm{TiH}_{2}$ alloy corrosion rate with the variation of $\mathrm{Zn}$ and $\mathrm{TiH}_{2}$ in Hank's solution at $37{ }^{\circ} \mathrm{C}$ was increased by the addition of 6 wt. $\% \mathrm{Zn}$ with 10 wt. $\% \mathrm{TiH}_{2}$. The corrosion resistance increased with addition of $\mathrm{Zn}$ content between 3 and 6 wt.\%. The presence of intermetallic $\mathrm{MgZn}$, which is potentially dangerous, is proved through corrosion morphologies, immersion testing and electrochemical measurements. Excessive $\mathrm{Zn}$ element of up to $10 \mathrm{wt}$. \% resulted in an intermetallic $\mathrm{MgZn}$ structure as a cathode and in acceleration of microgalvanic corrosion. Besides, based on immersion test, lower corrosion rates led to lower $\mathrm{pH}$ changes. The holes had shapes of small holes and needles. It indicated that the alloy contained $\mathrm{Mg}, \mathrm{Cl}$, and $\mathrm{O}$, as was apparent in the exixtence of $\mathrm{Mg}(\mathrm{OH})_{2}$ and $\mathrm{MgCl}_{2}$. $\mathrm{MgZn}, \mathrm{TiH}, \mathrm{Mg}(\mathrm{OH})_{2}$, $\mathrm{MgO}$, and $\mathrm{Ca}_{10}\left(\mathrm{PO}_{4}\right)_{6}(\mathrm{OH})_{2}$ peaks found after 72-hour immersion test.

\section{ACKNOWLEDGEMENT}

The authors would like to acknowledge the financial support from RISET IPTEKES, Ministry of Health Republic 
Indonesia. The authors would also like to thanks the Research Center of Metallurgy and Materials LIPI/BRIN for generously providing the use of test instruments.

\section{REFERENCES}

[1] Y. Wang, M. Wei, and J. Gao, "Improve corrosion resistance of magnesium in simulated body fl uid by dicalcium phosphate dihydrate coating," Mater. Sci. Eng. C, vol. 29, no. 4, pp. 1311-1316, 2009, doi: 10.1016/j.msec.2008.09.051.

[2] B. B. Levine, "A New Era in Porous Metals: Applications in Orthopaedics," no. 9, pp. 788-792, 2008, doi: 10.1002/adem.200800215.

[3] P. L. Franciska, A. Erryani, D. Annur, and I. Kartika, "condition The Effect of Thermal Pre-Treatment of Titanium Hydride ( $\mathrm{TiH} 2$ ) Powder in Argon Condition," vol. 020071, 2018, doi: 10.1063/1.5030293.

[4] W. Wang et al., "Magnesium alloy covered stent for treatment of a lateral aneurysm model in rabbit common carotid artery: An in vivo study," Sci. Rep., vol. 6, no. November, pp. 1-9, 2016, doi: 10.1038/srep37401.

[5] R. Nowosielski and A. Bajorek, "Corrosion behavior of bioresorbable Ca-Mg-Zn bulk metallic glasses," vol. 447, pp. 126-133, 2016, doi: 10.1016/j.jnoncrysol.2016.05.037.

[6] Y. B. Wang et al., "Acta Biomaterialia Biodegradable CaMgZn bulk metallic glass for potential skeletal application," vol. 7, pp. 3196-3208, 2011, doi: 10.1016/j.actbio.2011.04.027.

[7] A. Srinivasan, C. Blawert, Y. Huang, C. L. Mendis, K. U. Kainer, and $\mathrm{N}$. Hort, "ScienceDirect Corrosion behavior of $\mathrm{Mg}$ e Gd e $\mathrm{Zn}$ based alloys in aqueous $\mathrm{NaCl}$ solution," J. Magnes. Alloy., vol. 2, no. 3, pp. 245-256, 2014, doi: 10.1016/j.jma.2014.08.002.

[8] B. A. Atrens, G. Song, M. Liu, Z. Shi, F. Cao, and M. S. Dargusch, "Review of Recent Developments in the Field of Magnesium Corrosion **," pp. 1-54, 2015, doi: 10.1002/adem.201400434.

[9] M. P. Staiger, A. M. Pietak, J. Huadmai, and G. Dias, "Magnesium and its alloys as orthopedic biomaterials: A review," vol. 27, pp. 17281734, 2006, doi: 10.1016/j.biomaterials.2005.10.003.

[10] Y. I. N. Dong-song, Z. Er-lin, and Z. Song-yan, "Effect of Zn on mechanical property and corrosion property of extruded Mg-Zn-Mn alloy," pp. 1-6, 2008.

[11] L. Wang, B. Zhang, and T. Shinohara, "Corrosion behavior of AZ91 magnesium alloy in dilute $\mathrm{NaCl}$ solutions," Mater. Des., vol. 31, no. 2, pp. 857-863, 2010, doi: 10.1016/j.matdes.2009.07.049.

[12] M. L. Sciences et al., "Cellular and Molecular Life Sciences Aluminium in Alzheimer's disease : are we still at a crossroad ?," vol. 62, pp. 143158, 2005, doi: 10.1007/s00018-004-4317-3.

[13] Y. Y. Han, C. You, Y. Zhao, M. F. Chen, L. Wang, and C. You, "Effect of Mn Element Addition on the Microstructure, Mechanical Properties, and Corrosion Properties of $\mathrm{Mg}-3 \mathrm{Zn}-0$. 2Ca Alloy," vol. 6, no. December, pp. 1-10, 2019, doi: 10.3389/fmats.2019.00324.

[14] F. P. Lestari, F. Julhida, A. Erryani, and I. Kartika, "MICROSTRUCTURE AND MECHANICAL PROPERTIES BY ADDITION OF Zn AND TiH 2 IN QUARTERNARY Mg ALLOY FOAM," vol. 41, no. 1, pp. 8-15, 2018.

[15] I. Marco, "DEGRADATION TESTING OF MAGNESIUM AND ITS ALLOYS AIMING AT BIODEGRADABLE IMPLANT APPLICATIONS," no. December 2016.

[16] H. Waizy et al., "In vitro corrosion of ZEK100 plates in Hank' s Balanced Salt Solution," Biomed. Eng. Online, vol. 11, no. 1, p. 12, 2012, doi: 10.1186/1475-925X-11-12.

[17] Arthur C. Guyton; John E. Hall, Textbook of Medical Psycology Eleventh Edition.

[18] S. Sathish, U. S. Mallik, and T. N. Raju, "Corrosion Behavior of Cu-ZnNi Shape Memory Alloys," vol. 2013, no. March, pp. 49-54, 2013.

[19] B. A. Shaw, "Corrosion Resistance of Magnesium Alloys," vol. 13, 2003.
[20] X. Gu and Y. Zheng, "A review on magnesium alloys as biodegradable materials," vol. 4, no. 2, pp. 111-115, 2010, doi: 10.1007/s11706-0100024-1.

[21] M. Jamesh, S. Kumar, and T. S. N. S. Narayanan, "Corrosion behavior of commercially pure Mg and ZM21 Mg alloy in Ringer' $\mathrm{s}$ solution Long term evaluation by EIS," Corros. Sci., vol. 53, no. 2, pp. 645-654, 2011, doi: 10.1016/j.corsci.2010.10.011.

[22] Y. U. Lu, "Microstructure and Degradation Behaviour of Mg - Zn ( - Ca ) Alloys," 2014.

[23] S. Cai, T. Lei, N. Li, and F. Feng, "Effects of Zn on microstructure, mechanical properties and corrosion behavior of Mg-Zn alloys," Mater. Sci. Eng. C, vol. 32, no. 8, pp. 2570-2577, 2012, doi: 10.1016/j.msec.2012.07.042.

[24] H. R. Bakhsheshi-rad, M. H. Idris, M. R. Abdul-kadir, A. Ourdjini, M. Medraj, and M. Daroonparvar, "Mechanical and bio-corrosion properties of quaternary $\mathrm{Mg}-\mathrm{Ca}-\mathrm{Mn}-\mathrm{Zn}$ alloys compared with binary $\mathrm{Mg}-\mathrm{Ca}$ alloys," Mater. Des., vol. 53, pp. 283-292, 2014, doi: 10.1016/j.matdes.2013.06.055.

[25] E. Zhang, L. Yang, J. Xu, and H. Chen, "Acta Biomaterialia Microstructure, mechanical properties and bio-corrosion properties of $\mathrm{Mg}-\mathrm{Si}(-\mathrm{Ca}, \mathrm{Zn})$ alloy for biomedical application q," Acta Biomater. vol. 6, no. 5, pp. 1756-1762, 2010, doi: 10.1016/j.actbio.2009.11.024. 